FIGHTING FOR

FAITH

AND

NATION 
University of Pennsylvania Press

SERIES IN CONTEMPORARY ETHNOGRAPHY

Dan Rose and Paul Stoller, Series Editors

A complete list of books in the series

is available from the publisher. 


\section{FIGHTING FOR}

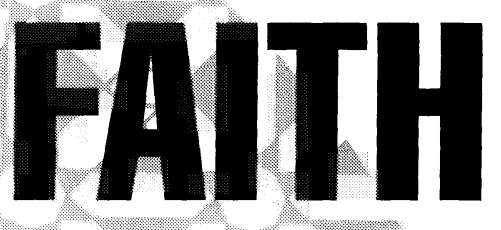

\section{AND}

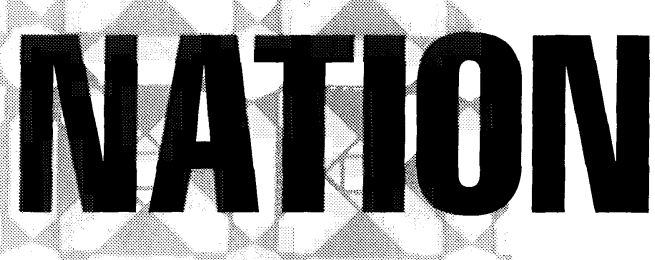

\section{DIALOGUES \\ WITH SIKH MILITANTS}

\section{CYNTHIA KEPPLEY MAHMOOD}

PENN

University of Pennsylvania Press

Philadelphia 
Copyright (C) 1996 Cynthia Keppley Mahmood

All rights reserved

Printed in the United States of America on acid-free paper

1098765432

Published by

University of Pennsylvania Press

Philadelphia, Pennsylvania 19104-6097

Library of Congress Cataloging-in-Publication Data

Mahmood, Cynthia Keppley.

Fighting for faith and nation : dialogues with Sikh militants / Cynthia Keppley Mahmood.

p. cm. - (Series in contemporary ethnography)

Includes bibliographical references and index.

ISBN 0-8122-3361-1 (alk. paper). — ISBN 0-8122-1592-3 (alk.

paper)

1. Sikhs-Politics and government. 2. Punjab (India)-Politics

and government. 3. Human rights-India-Punjab. 4. Sikhism.

I. Title. II. Series.

DS485.P88M25 1997

$954.91^{\prime} 4^{\prime} 00882946$-dc20 